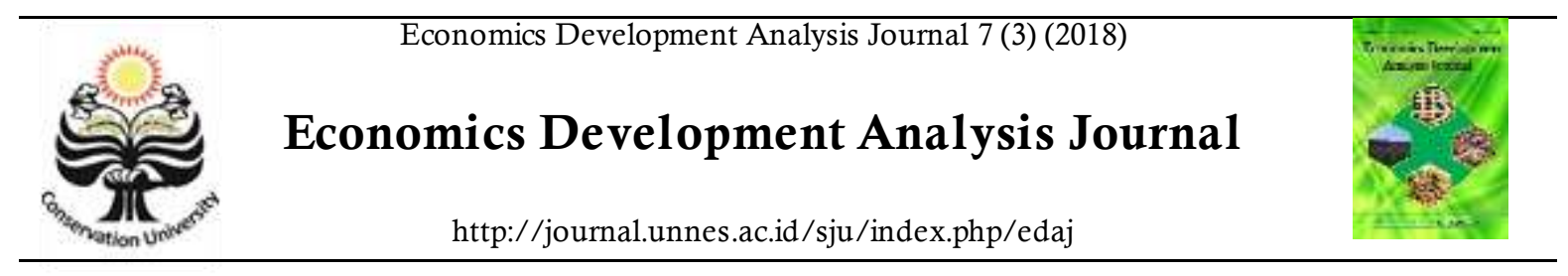

\title{
Sektor Unggulan dan Keterkaitan Spasial Ekonomi Antar Kabupaten/Kota di Jawa Tengah
}

\author{
Muhammad Tsaaqibul Fikri $^{1 凶}$, Fafurida $^{2}$ \\ Jurusan Ekonomi Pembangunan, Fakultas Ekonomi, Universitas Negeri Semarang
}

\begin{tabular}{|c|c|}
\hline Info Artikel & Abstrak \\
\hline Sejarah Artikel: & ujuan dari penelitian ini adalah untuk mengidentifikasi sektor apa saja yang menjadi unggulan \\
\hline Diterima April 2017 & abupaten/kota di Jawa Tengah dan bagaimana keterkaitan spasialnya. Penelitian ini dilakukan \\
\hline Disetujui Juni 2017 & dengan menggunakan alat analisis LQ, Shift-Share dan Tipologi Klassen untuk mengetahui sektor \\
\hline Dipublikasikan Agustus & dengan keunggulan komparatif dan kompetitif. Indeks Moran dan LISA untuk mengetahui \\
\hline 2017 & $\begin{array}{l}\text { keterkaitan spasial antar daerah secara global dan lokal. Hasil penelitian ini menunjukkan sektor } \\
\text { unggulan yang mayoritas dimiliki kabupaten/kota di Jawa Tengah adalah sektor jasa-jasa, sektor }\end{array}$ \\
\hline Keywords: & pertanian serta sektor pertambangan dan penggalian. Adapun hasil dari analisis keterkaitan spasial \\
\hline Superb Con & kabupaten/kota di Jawa Tengah terdapat keterkaitan spasial yang signifikan dan bernilai high-high \\
\hline Correlation; Spatial; & (hot-spot) pada sektor pertanian di kawasan Kabupaten Banjarnegara, Kabupaten Wonosobo dan \\
\hline Economy; Moran Indeks; & Kabupaten Blora, sektor pertambangan dan penggalian di kawasan Kabupaten Blora, sektor industri \\
\hline LISA & $\begin{array}{l}\text { pengolahan di kawasan Kabupaten Jepara dan sektor jasa-jasa di kawasan Kabupaten Magelang. } \\
\text { Sehingoa keterkaitan tersebut dapat meniadi dasar untuk membentuk keriasama antar }\end{array}$ \\
\hline
\end{tabular}

\section{Abstract}

The purpose of this study was to determine what sectors of the superior districts / cities in Central Javaandhow the spatial correlation patterns did. This research was conducted using LQ, Shift-Share and TypologyKlassen to determine sectors with comparative advantages and competitiveness, Index Moran and LISA to determinethe spatial correlation between the districts / cities. The results of this study indicated that the majorityofthesuperior sectors of the districts /cities in Central Java are in sector services, the agricultural sector and in mining and excavating sector. The results of the analysis of the spatial correlation patterns in districts / citiesin CentralJava are significant spatial correlation pattrens and valuable high-high (hot-spot) in the agricultural sector in Banjarnegara, Wonosobo and Blora area, mining and excavatinf sector in Blora area, the manufacturingsector in the region of Jepara district and service sector in Magelang regency area. So that the association can bethe basis to establish cooperation between districts / cities that development can be made more equitable..

\footnotetext{
${ }^{\square}$ Alamat korespondensi:

Ruang Jurnal Gedung L FE UNNES, Sekaran Gunungpati

Semarang, 50229, Indonesia

E-mail: edaj@mail.unnes.ac.id
} ISSN 2252-6965 


\section{PENDAHULUAN}

Permasalahan ketimpangan antar kabupaten/kota masih terjadi di Jawa Tengah dan cenderung semakin meningkat. Pada tahun 2011 pertumbuhan PDRB Provinsi Jawa Tengah sebesar $5,30 \%$ meningkat menjadi $5,42 \%$ pada tahun 2014. Sedangkan ketimpangan antar sektor yang ditunjukkan indeks williamson antar sektor terlihat cenderung menurun pada tahun 2010-2014. Namun dengan meningkatnya pertumbuhan PDRB dan menurunnya ketimpangan antar sektor di Provinsi Jawa Tengah tersebut juga diikuti dengan meningkatnya ketimpangan antar kabupaten/kota di Provinsi Jawa Tengah. Hal ini seperti yang terlihat pada tabel 1.1.

Tabel 1. PDRB, Pertumbuhan PDRB, Indeks Williamson Antar Sektor \& Antar Kab/Kota ADHK 2010 di Jawa Tengah Tahun 2010-2014

\begin{tabular}{lllll}
\hline Tahun & $\begin{array}{l}\text { PDRB } \\
\text { (Juta Rupiah) }\end{array}$ & $\begin{array}{l}\text { Pertumbuhan } \\
\text { PDRB }\end{array}$ & $\begin{array}{l}\text { Indeks Williamson } \\
\text { Antar Sektor }\end{array}$ & $\begin{array}{l}\text { Indeks Williamson } \\
\text { Antar Kab/Kota }\end{array}$ \\
\hline 2010 & $623.224 .621,33$ & - & 0,5519 & 0,6246 \\
2011 & $656.268 .129,91$ & 5,30 & 0,5257 & 0,6233 \\
2012 & $691.343 .115,96$ & 5,34 & 0,5108 & 0,6336 \\
2013 & $726.899 .706,38$ & 5,14 & 0,5571 & 0,6359 \\
2014 & $766.271 .771,27$ & 5,42 & 0,5237 & 0,6451 \\
\hline
\end{tabular}

Sumber: Badan Pusat Statistik Jawa Tengah, 2015

Terjadinya ketimpangan wilayah berimplikasi pada tingkat kesejahteraan masyarakat antar wilayah yang timpang dan dapat memicu konflik sosial. Karena itu, aspek ketimpangan antar wilayah ini perlu ditanggulangi melalui kebijakan pembangunan wilayah oleh pemerintah daerah.

Berdasarkan Peraturan Daerah Provinsi Jawa Tengah Nomor 21 Tahun 2003 tentang Rencana Tata Ruang Wilayah Provinsi Jawa Tengah Tahun 2009 - 2029 ditetapkan 8 kawasan andalan yang merupakan kawasan strategis pengembangan wilayah. Delapan kawasan tersebut terdiri dari Kedungsepur, Barlingmascakeb, Purwomanggung, Subosukowonosraten, Banglor, Wanarakurti, Tangkallangka dan Bregas. Tujuan terbentuknya kawasan antar daerah kabupaten/kota ini adalah untuk daerah dalam satu kawasan saling bekerjasama dan berupaya meningkatkan pertumbuhan ekonomi sekaligus meningkatkan pemerataan pendapatan.

Namun rupa-rupanya kerjasama antara daerah dalam rangka mengembangkan potensi, daya saing dan pemerataan pembangunan itu sejauh ini masih belum optimal. Sebagian forum kerjasama tersebut hanya berhenti di MoU.
Diantara kabupaten/kota belum menemukan kata sepakat bagaimana bersinergi dalam kerjasama tersebut (Hakim, 2013:274).

Berdasarkan latar belakang yang telah dijelaskan di atas, maka perlu dilakukan studi mengenai sektor unggulan kabupaten/kota di Jawa Tengah dan keterkaitan spasial ekonomi antar kabupaten/kota berdasarkan sektor unggulannya tersebut. Sehingga keterkaitan spasial tersebut dapat menjadi dasar pembentukan kerjasama antar kabupaten/kota yang lebih optimal dalam mengembangkan potensi, daya saing dan pemerataan pembangunan. Tujuan dari penelitian ini adalah untuk mengidentifikasi sektor apa saja yang menjadi sektor unggulan kabupaten/kota di wilayah Provinsi Jawa Tengah dan mengidentifikasi keterkaitan spasialnya.

\section{METODE PENELITIAN}

Jenis penelitian ini adalah penelitian kuantitatif. Martono (2010:20) mendefinisikan penelitian kuantitatif sebagai penelitian yang dilakukan dengan mengumpulkan data berupa angka. Data yang berupa angka tersebut kemudian diolah dan dianalisis untuk 
mendapatkan suatu informasi ilmiah di balik angka-angka tersebut.

Jenis data yang digunakan dalam penelitian ini adalah data sekunder. Data sekunder yang digunakan dalam penelitian ini adalah data PDRB kabupaten/kota di Jawa Tengah dan PDRB Provinsi Jawa Tengah tahun 2010-2014 yang diperoleh melalui dokumen publikasi dari Badan Pusat Statistik (BPS). Data sekunder lain yang digunakan dalam penelitian ini adalah data spasial yang berupa peta administratif kabupaten/kota di Jawa Tengah yang diperoleh melalui Global Administrative Area.

Alat analisis yang digunakan dalam penelitian ini adalah LQ, Shift-share, Tipologi Klassen, Indeks Moran dan LISA. Analisis LQ, Shift-share dan Tipologi Klassen digunakan untuk mengetahui sector yang memiliki keunggulan komparatif dan kompetitif. Menurut Tarigan (2012:82) Location Questient (LQ) adalah suatu perbandingan tentang besarnya peranan suatu sektor/industri di suatu daerah terhadap besarnya peranan suatu sektor/industri tersebut secara nasional. Analisis shift-share digunakan untuk menganalisis dan mengetahui keunggulan kompetitif. Sedangkan Tipologi Klassen digunakan untuk mengkombinasikan hasil analisis LQ dan Shift-share, sehingga dapat diketahui sektor yang memiliki keunggulan komparatif sekaligus kompetitif. Setelah diketahui keunggulan sektor ekonomi masingmasing kabupaten/kota selanjutnya digunakan analisis indeks Moran untuk mengetahui keterkaitan spasial seluruh kabupaten/kota di Jawa Tengah secara global berdasarkan sektor unggulannya. Rentang nilai dari Indeks Moran adalah $-1 \leq \mathrm{I} \leq 1$. Nilai $-1 \leq \mathrm{I}<0$ menunjukkan adanya autokorelasi spasial negatif, sedangkan nilai $0<\mathrm{I} \leq 1$ menunjukkan adanya autokorelasi spasial positif, nilai Indeks Untuk menguji signifikansi keterkaitan (autokorelasi) spasial dilakukan uji signifikansi indeks Moran. Pada taraf $\alpha=5 \%$, keterkaitan (autokorelasi) spasial dapat dikatakan signifikan jika nilai $Z(I)<-1,96$ atau $Z(I)>1,96$. Sealin analisis indeks Moran global juga digunakan analisis LISA untuk mengetahui keterkaitan spasial lokal antara kabupaten/kota dengan kabupaten/kota tetangganya di Jawa Tengah.

\section{HASIL DAN PEMB AHASAN}

\section{Sektor Unggulan}

Dalam penelitian ini, seluruh kabupaten/kota yang berada di Provinsi Jawa Tengah dianalisis menggunakan analisis Location Quetient (LQ) untuk mengetahui sektor-sektor yang memiliki keunggulan komparatif, analisis Shift-Share untuk mengetahui sektor-sektor yang memiliki keunggulan kompetitif dan analisis Klassen Typologi untuk mengkombinasikan hasil dari analisis LQ dan analisis Shift-Share, sehingga dapat diketahui sektor-sektor yang memiliki keunggulan komparatif dan kompetitif.

Berdasarkan hasil analisis LQ, shift-share dan tipologi klassen dapat diketahui bahwa daerah yang memiliki keunggulan komparatif dan kompetitif pada 9 sektor ekonomi, yaitu: 1) Sektor pertanian terdiri dari Kab. Banjarnegara, Kab. Batang, Kab. Boyolali, Kab. Brebes, Kab. Jepara, Kab. Kebumen, Kab. Kendal, Kab. Pati, Kab. Pemalang, Kab. Purbalingga, Kab. Temanggung, Kab. Wonogiri dan Kab. Wonosobo; 2) Sektor pertambangan dan penggalian terdiri dari Kab. Banjarnegara, Kab. Banyumas, Kab. Batang, Kab. Blora, Kab. Boyolali, Kab. Kebumen, Kab. Magelang, Kab. Pekalongan, Kab. Pemalang, Kab. Purbalingga, $\mathrm{Kab}$. Sragen, Kab. Tegal dan Kab. Wonogiri; 3) Sektor Industri terdiri dari Kab. Karanganyar, Kab. Kendal, Kab. Semarang dan Kab. Sukoharjo; 4) Sektor listrik, gas dan air bersih terdiri dari Kab. Jepara, Kab. Karanganyar, Kab. Kendal, Kabupaten Klaten, Kab. Pekalongan, Kabupaten Pemalang, Kab. Sragen, Kab. Sukoharjo dan Kota Magelang; 5) Sektor bangunan terdiri dari Kab. Semarang, Kota Pekalongan, Kota Salatiga dan Kota Tegal; 6) Sektor perdagangan, hotel dan restoran terdiri dari Kab. Banjarnegara, Kab. Banyumas, Kab. Blora, Kab. Brebes, Kab. Demak, Kab. Pati, $\mathrm{Kab}$. Sragen, Kab. Temanggung, Kab. Wonosobo, Kota Salatiga, Kota Surakarta dan Kota Tegal; 7) Sektor pengangkutan dan komunikasi terdiri dari Kabupaten Banjarnegara 
Kabupaten Boyolali, Kabupaten Magelang, Kabupaten Purworejo, Kabupaten Sukoharjo, Kota Magelang, Kota Semarang dan Kota Surakarta; 8) Sektor keuangan, persewaan dan jasa perusahaan terdiri dari Kabupaten Karanganyar, Kabupaten Magelang, Kabupaten Purworejo, Kabupaten Sukoharjo, Kota Magelang, Kota Semarang dan Kota Surakarta; 9)Sektor jasa-jasa terdiri dari Kab. Banjarnegara, Kab. Batang, Kab. Blora, Kab. Boyolali, Kab. Jepara, Kab. Kebumen, Kab. Klaten, Kab. Magelang, Kab. Pati, Kab. Pekalongan, Kab. Purbalingga, Kab. Purworejo, Kab. Rembang, $\mathrm{Kab}$. Sragen, Kab. Temanggung, Kab. Wonogiri dan Kab. Wonosobo.

\section{Keterkaitan Spasial}

Melalui analisis pola keterkaitan spasial sektor-sektor ekonomi antar kabupaten/kota ini diharapkan sektor-sektor unggulan tersebut tidak hanya dapat dikembangkan di masing-masing kabupaten/kota, namun juga dapat dibentuk pola kerjasama regional antar kabupaten/kota di Provinsi Jawa Tengah untuk mengembangkan sektor tersebut berdasarkan keterkaitan spasialnya, sehingga pembangunan dapat dilakukan lebih merata. Hasil analisis keterkaitan spasial ini berupa nilai indeks Moran yang menunjukkan tingkat keterkaitan spasial sektor ekonomi antar kabupaten/kota secara global di Jawa Tengah dan analisis Local Indicator of Spatial Autocorrelation (LISA) yang menunjukkan pola keterkaitan spasial sektor ekonomi secara lokal antar kabupaten/kota dengan kabupaten/kota tetangganya di Jawa Tengah. Berikut ini dijelaskan pola keterkaitan spasial secara lebih lengkap berdasarkan sektor-sektor ekonomi antar kabupaten/kota di Jawa Tengah:

\section{Sektor Pertanian}

Nilai indeks Moran pada sektor pertanian sebesar -0,0123364 dengan nilai z (z-value) sebesar 0,2852 , artinya secara global keterkaitan spasial kabupaten/kota di Provinsi Jawa Tengah pada sektor pertanian memiliki keterkaitan spasial negatif (cenderung menyebar) dan tidak signifikan. Hasil pengujian Local Indicator of Spatial Autocorrelation (LISA) terhadap keterkaitan spasial sektor pertanian masing- masing kabupaten/kota di Jawa Tengah dengan kabupaten/kota tetangganya tergambar dalam LISA Cluster Map pada gambar 1.

Berdasarkan LISA cluster map sektor pertanian pada gambar 1 dapat diketahui terdapat pola keterkaitan spasial local cluster (menggerombol dan saling mempengaruhi) yang bernilai high-high (hot-spot) dan signifikan di kawasan: 1) Kab. Banjarnegara dan Kab. Wonosobo dengan daerah tetangganya (Kab. Purbalingga, Kab. Banyumas, Kab. Kebumen, Kab. Purworejo, Kab. Magelang, Kab. Purworejo, Kab. Temanggung, Kab. Kendal, $\mathrm{Kab}$. Batang dan Kab. Pekalongan). 2) Kawasan Kabupaten Blora dengan daerah tetangganya (Kab. Rembang, Kab. Grobogan dan Kab. Pati). Sehingga kedua kawasan ini dapat dijadikan fokus pengembangan sektor pertanian dengan membentuk kerjasama antar daerah utama dengan daerah tetangganya, terutama daerah yang sudah memiliki keunggulan komparatif dan kompetitif.

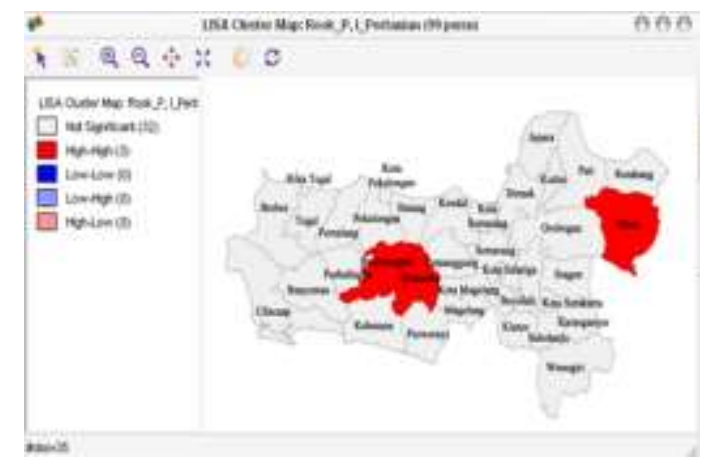

Gambar 1. LISA Cluster Map Sektor Pertanian Kabupaten/Kota di Jawa Tengah

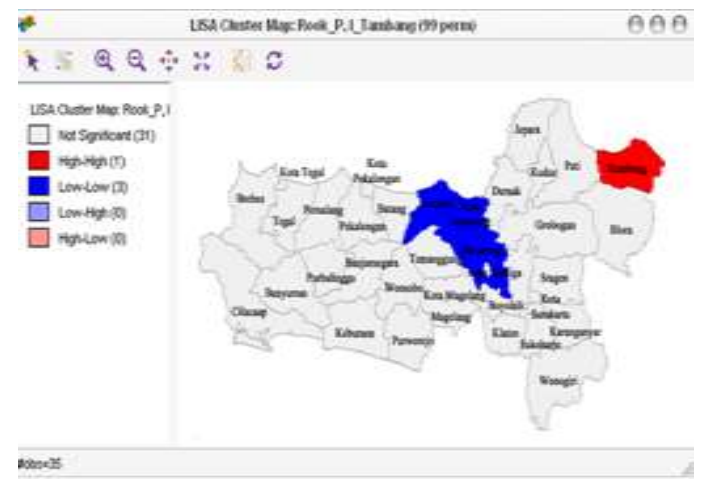

Gambar 2. LISA Cluster Map Sektor

Pertambangan dan Penggalian Kabupaten/Kota di Jawa Tengah 


\section{Sektor Pertambangan dan Penggalian}

Nilai indeks Moran pada sektor pertambangan dan penggalian sebesar 0,1047 dengan nilai $\mathrm{z}$ ( $z$-value) sebesar 1,4867 , artinya secara global keterkaitan spasial kabupaten / kota di Provinsi Jawa Tengah pada sektor pertambangan dan penggalian memiliki keterkaitan spasial positif (cenderung menggerombol) dan tidak signifikan. Hasil pengujian Local Indicator of Spatial Autocorrelation (LISA) terhadap keterkaitan spasial sektor pertambangan dan penggalian masing-masing kabupaten/kota di Jawa Tengah dengan kabupaten/kota tetangganya tergambar dalam LISA Cluster Map pada gambar 2.

Berdasarkan LISA cluster map sektor pertambangan \& penggalian pada gambar 2 dapat diketahui terdapat pola keterkaitan spasial local cluster (menggerombol dan saling mempengaruhi yang bernilai high-high (hot-spot) dan signifikan di kawasan Kab. Rembang dan tetangganya (Kab. Pati dan Kab. Blora). Sehingga kawasan ini dapat dijadikan fokus pengembangan sektor pertambangan dan penggalian dengan membentuk kerjasama antar daerah utama dengan daerah tetangganya,

\section{Sektor Industri Pengolahan}

Nilai indeks Moran pada sektor industri pengolahan sebesar -0,0999 dengan nilai z ( $z$ value) sebesar -0,7028, artinya secara global keterkaitan spasial kabupaten/kota di Provinsi Jawa Tengah pada sektor industri pengolahan memiliki keterkaitan spasial negatif (cenderung menyebar) dan tidak signifikan. Hasil pengujian Local Indicator of Spatial Autocorrelation (LISA) terhadap keterkaitan spasial sektor industri pengolahan masing-masing kabupaten/kota di Jawa Tengah dengan kabupaten/kota tetangganya tergambar dalam LISA Cluster Map pada gambar 3 .

Berdasarkan LISA cluster map sektor industri pengolahan pada gambar 3 dapat diketahui terdapat pola keterkaitan spasial local cluster (menggerombol dan saling mempengaruhi) yang bernilai high-high (hot-spot) dan signifikan di kawasan Kab. Jepara dan tetangganya (Kab. Demak, Kab. Kudus dan Kab.
Pati). Sehingga kawasan ini dapat dijadikan fokus pengembangan sektor industri pengolahan dengan membentuk kerjasama antar daerah utama dengan daerah tetangganya.

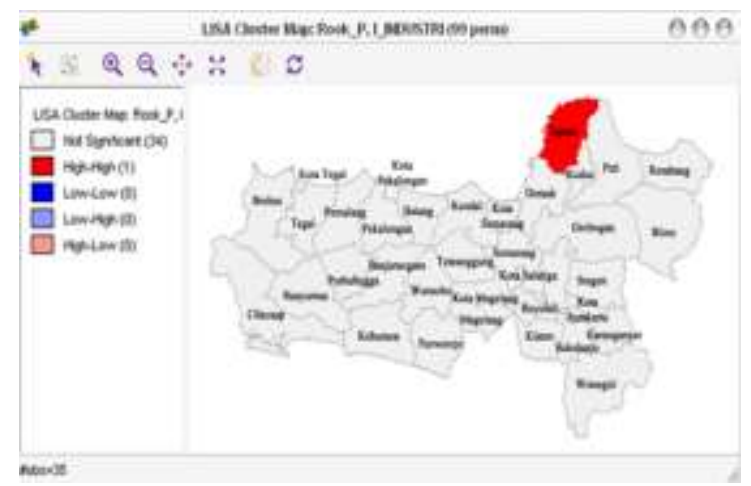

Gambar 3. LISA Cluster Map Sektor Industri Pengolahan Kabupaten/Kota di Jawa Tengah

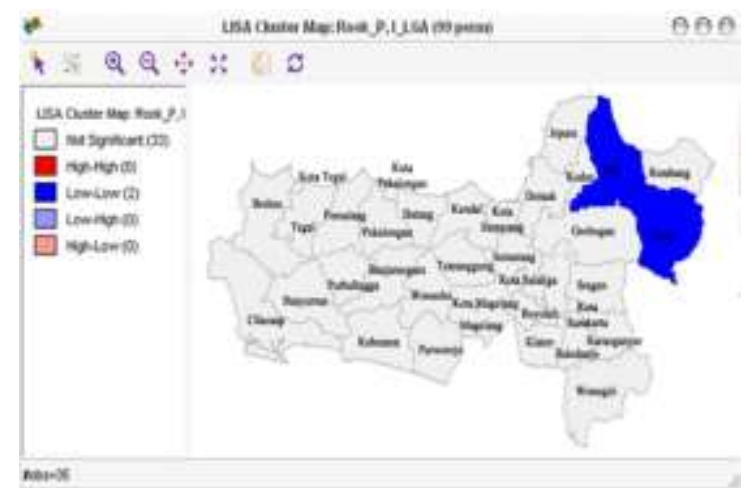

Gambar 4. LISA Cluster Map Sektor Listrik, Gas \& Air Bersih Kabupaten/Kota di Jawa Tengah

\section{Sektor Listrik, Gas \& Air B ersih}

Nilai indeks Moran pada sektor listrik, gas \& air bersih sebesar $-0,0608$ dengan nilai z ( $z$ value) sebesar -0,2663, artinya secara global keterkaitan spasial kabupaten/kota di Provinsi Jawa Tengah pada sektor listrik, gas \& air bersih memiliki keterkaitan spasial negatif (cenderung menyebar) dan tidak signifikan. Hasil pengujian Local Indicator of Spatial Autocorrelation (LISA) terhadap keterkaitan spasial sektor listrik, gas \& air bersih masing-masing kabupaten / kota di Jawa Tengah dengan kabupaten / kota tetangganya tergambar dalam LISA Cluster Map pada gambar 4 .

Berdasarkan LISA cluster map sektor industri pengolahan pada gambar 4 dapat 
diketahui tidak terdapat pola keterkaitan spasial local cluster (menggerombol dan saling mempengaruhi) yang bernilai high-high (hot-spot) dan signifikan. Sehingga tidak terdapat kawasan yang dapat dijadikan kawasan kerjasama untuk pengembangan sektor listrik, gas \& air bersih antar kabupaten/kota pada suatu kawasan.

\section{Sektor B angunan}

Nilai indeks Moran pada sektor bangunan sebesar -0,0269 dengan nilai z (z-value) sebesar 0,1087 , artinya secara global keterkaitan spasial kabupaten/kota di Provinsi Jawa Tengah pada sektor bangunan memiliki keterkaitan spasial negatif (cenderung menyebar) dan tidak signifikan. Hasil pengujian Local Indicator of Spatial Autocorrelation (LISA) terhadap keterkaitan spasial sektor bangunan masingmasing kabupaten/kota di Jawa Tengah dengan kabupaten/kota tetangganya tergambar dalam LISA Cluster Map pada gambar 5.

Berdasarkan LISA cluster map sektor bangunan pada gambar 5 dapat diketahui tidak terdapat pola keterkaitan spasial local cluster (menggerombol dan saling mempengaruhi) yang bernilai high-high (hot-spot) dan signifikan. Sehingga tidak terdapat kawasan yang dapat dijadikan kawasan kerjasama untuk pengembangan sektor bangunan antar kabupaten/kota pada suatu kawasan.

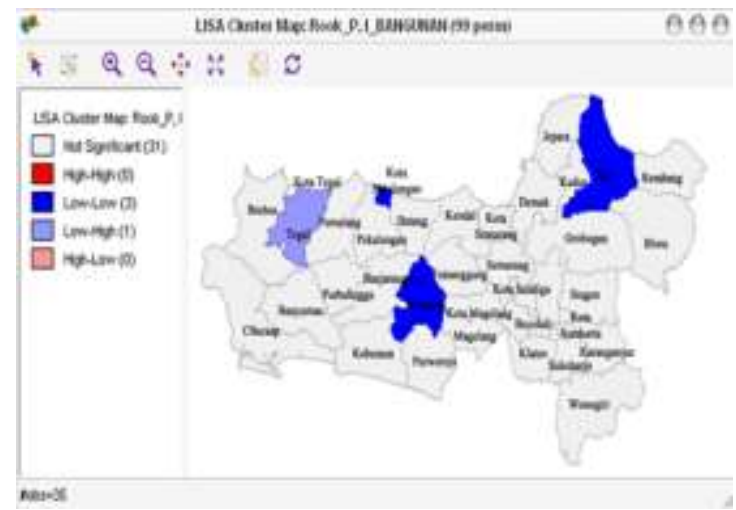
$\operatorname{\theta e\theta }$

Gambar 5. LISA Cluster Map Sektor Bangunan Kabupaten/Kota di Jawa Tengah

\section{Sektor Perdagangan, Hotel \& Restoran}

Nilai indeks Moran pada sektor perdagangan, hotel \& restoran sebesar -1,0038 dengan nilai $\mathrm{z}$ ( $z$-value) sebesar 0,1087 , artinya secara global keterkaitan spasial kabupaten/kota di Provinsi Jawa Tengah pada sektor perdagangan, hotel \& restoran memiliki keterkaitan spasial negatif (cenderung menyebar) dan tidak signifikan. Hasil pengujian Local Indicator of Spatial Autocorrelation (LISA) terhadap keterkaitan spasial sektor perdagangan, hotel \& restoran masing-masing kabupaten / kota di Jawa Tengah dengan kabupaten/kota tetangganya tergambar dalam LISA Cluster Map pada gambar 6 .

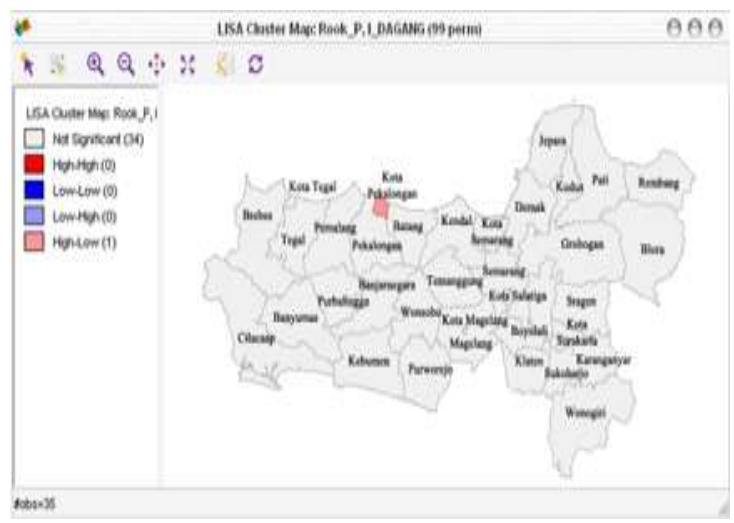

Gambar 6. LISA Cluster Map Sektor Perdagangan, Hotel \& Restoran Kabupaten/Kota di Jawa Tengah

Berdasarkan LISA cluster map sektor perdagangan, hotel \& restoran pada gambar 6 dapat diketahui tidak terdapat pola keterkaitan spasial local cluster (menggerombol dan saling mempengaruhi) yang bernilai high-high (hot-spot) dan signifikan. Sehingga tidak terdapat kawasan yang dapat dijadikan kawasan kerjasama untuk pengembangan sektor perdagangan, hotel \& restoran antar kabupaten/kota pada suatu kawasan.

\section{Sektor Pengangkutan \& Komunikasi}

Nilai indeks Moran pada sektor pengangkutan \& komunikasi sebesar -1,0702 dengan nilai z (z-value) sebesar -0,3589, artinya secara global keterkaitan spasial kabupaten/kota di Provinsi Jawa Tengah pada sektor pengangkutan \& komunikasi memiliki keterkaitan spasial negatif (cenderung menyebar) dan tidak signifikan. Hasil pengujian Local Indicator of Spatial Autocorrelation (LISA) terhadap 
keterkaitan spasial sektor pengangkutan \& komunikasi masing-masing kabupaten / kota di Jawa Tengah dengan kabupaten/kota tetangganya tergambar dalam LISA Cluster Map pada gambar 7 .

Berdasarkan LISA cluster map sektor pengangkutan \& komunikasi pada gambar 7 dapat diketahui tidak terdapat pola keterkaitan spasial local cluster (menggerombol dan saling mempengaruhi) yang bernilai high-high (hot-spot) dan signifikan. Sehingga tidak terdapat kawasan yang dapat dijadikan kerjasama untuk pengembangan sektor pengangkutan \& komunikasi antar kabupaten/kota pada suatu kawasan.

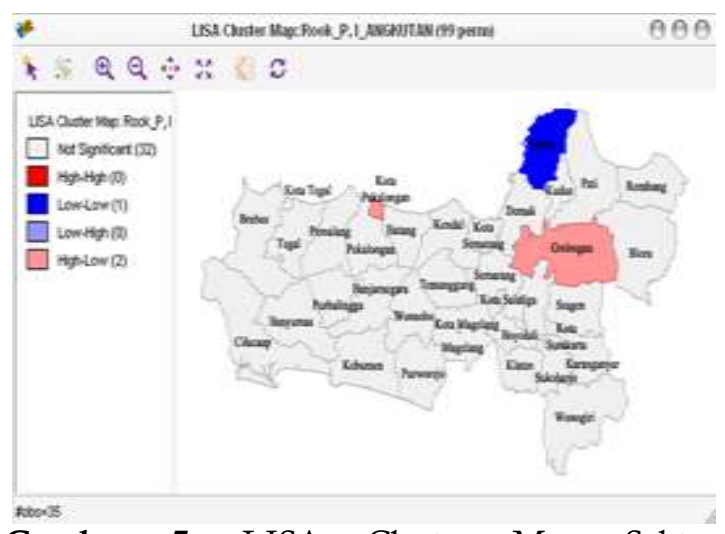

Gambar 7. LISA Cluster Map Sektor Pengangkutan \& Komunikasi Kabupaten/Kota di Jawa Tengah

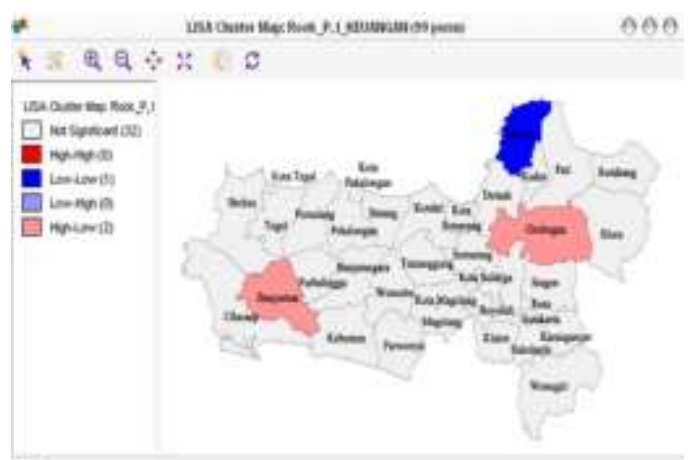

Gambar 8. LISA Cluster Map Sektor Keuangan, Persewaan \& Jasa Perusahaan Kabupaten/Kota di Jawa Tengah

\section{Sektor Keuangan, Persewaan \& Jasa Perusahaan}

Nilai indeks Moran pada sektor keuangan, persewaan \& jasa perusahaan sebesar -0,0121 dengan nilai $\mathrm{z}$ ( $z$-value) sebesar 0,1675 , artinya secara global keterkaitan spasial kabupaten/kota di Provinsi Jawa Tengah pada sektor keuangan, persewaan \& jasa perusahaan memiliki keterkaitan spasial negatif (cenderung menyebar) dan tidak signifikan. Hasil pengujian Local Indicator of Spatial Autocorrelation (LISA) terhadap keterkaitan spasial sektor keuangan, persewaan \& jasa perusahaan masing-masing kabupaten / kota di Jawa Tengah dengan kabupaten/kota tetangganya tergambar dalam LISA Cluster Map pada gambar 8 .

Berdasarkan LISA cluster map sektor keuangan, persewaan \& jasa perusahaan pada gambar 8 dapat diketahui tidak terdapat pola keterkaitan spasial local cluster (menggerombol dan saling mempengaruhi) yang bernilai high-high (hot-spot) dan signifikan. Sehingga tidak terdapat kawasan yang dapat dijadikan kerjasama untuk pengembangan sektor keuangan, persewaan \& jasa perusahaan antar kabupaten/kota pada suatu kawasan.

\section{Sektor Jasa-Jasa}

Nilai indeks Moran pada sektor jasa-jasa sebesar 0,0639 dengan nilai z ( $z$-value) sebesar 0,8063 , artinya secara global keterkaitan spasial kabupaten/kota di Provinsi Jawa Tengah pada sektor jasa-jasa memiliki keterkaitan spasial positif (cenderung menggerombol) dan tidak signifikan. Hasil pengujian Local Indicator of Spatial Autocorrelation (LISA) terhadap keterkaitan spasial sektor jasa-jasa masingmasing kabupaten / kota di Jawa Tengah dengan kabupaten/kota tetangganya tergambar dalam LISA Cluster Map pada gambar 9.

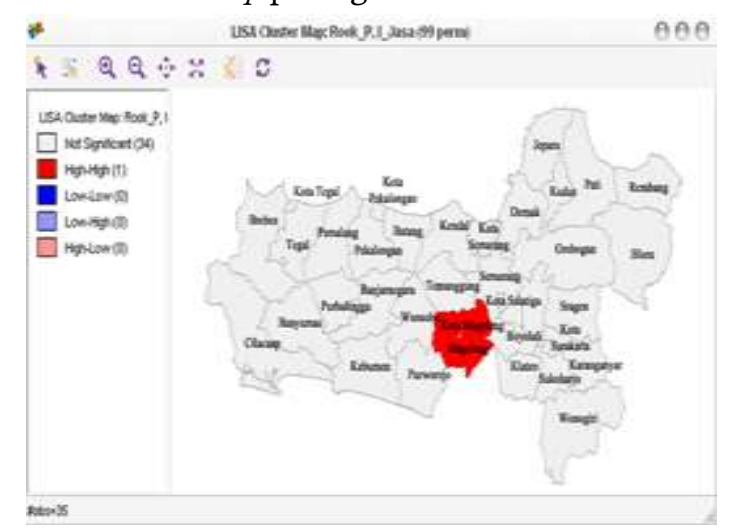

Gambar 9. LISA Cluster Map Sektor Jasa-Jasa Perusahaan Kabupaten/Kota di Jawa Tengah 
Berdasarkan LISA cluster map sektor jasajasa pada gambar 9 dapat diketahui terdapat pola keterkaitan spasial local cluster (menggerombol dan saling mempengaruhi) yang bernilai high-high (hot-spot) dan signifikan di kawasan Kab. Magelang dengan kabupaten tetangganya (Kabuaten Purworejo, Kabupaten Wonosobo, Kabupaten Temanggung, Kabupaten Boyolali Kabupaten Semarang dan Kota Magelang). Sehingga kawasan ini dapat dijadikan fokus pengembangan sektor jasa-jasa dengan membentuk kerjasama antar Kabupaten Magelang dengan kabupatenkabupaten tetangganya yang juga memiliki keunggulan kompetitif maupun komparatif pada sektor jasajasa dalam kawasan ini yaitu Kabuaten Purworejo, Kabupaten Wonosobo, Kabupaten Temanggung, Kabupaten Boyolali dan Kota Magelang.

\section{SIMPULAN}

Hasil dari penelitian ini menunjukkan sektor unggulan yang mayoritas dimiliki kabupaten/kota di Jawa Tengah adalah sektor jasa-jasa, sektor pertanian serta sektor pertambangan dan penggalian. Adapun hasil dari analisis pola keterkaitan spasial kabupaten/kota di Jawa Tengah secara global tidak terdapat keterkaitan spasial yang signifikan. Sedangkan secara lokal terdapat pola keterkaitan spasial yang signifikan dan bernilai high-high (hot-spot) pada sektor pertanian di kawasan Kabupaten Banjarnegara, Kabupaten Wonosobo dan Kabupaten Blora, sektor pertambangan dan penggalian di kawasan Kabupaten Blora, sektor industri pengolahan di kawasan Kabupaten Jepara serta sektor jasajasa di kawasan Kabupaten Magelang. .

\section{DAFTAR PUSTAKA}

Badan Pusat Statistik Provinsi Jawa Tengah. 2015. Tinjauan PDRB Kabupaten/Kota Se-Jawa Tengah 2014. Semarang: Badan Pusat Statistik Provinsi Jawa Tengah.

Produk Domestik Regional Bruto Menurut Lapangan Usaha Jawa Tengah 2010-2014.
Semarang: Badan Pusat Statistik Provinsi Jawa Tengah.

Fafurida,-..(2012) Perencanaan Pengembangan Sektor Pertanian Sub Sektor Tanaman Pangan Di Kabupaten Kulonprogo. JEJAK: Jurnal Ekonomi dan Kebjakan, 2(2). Doi:http://dx.doi.org/10.15294/jejak.v2i2.14 67

Hakim, Lukman. 2013. Indonesia Government Index 2012: Tantangan Tata Kelola Pemerintahan di 33 Provinsi. Jakarta Selatan: The Partnership for Governance Reform.

Martono, Nanang. 2010. Metode Penelitian Kuantitatif: Analisis Isi dan Analisis Data Sekunder. Jakarta: Rajagrafindo Persada.

Setyowati, .... (2015). Analisis Pengembangan Sektor Potensial Kabupaten Klaten Dalam Kawasan Subosukawonosraten. Economics Development Analysis Journal, 3(4). doi:10.15294/edaj.v3i4.2526.

Tarigan, Robinson. 2012. Ekonomi Regional: Teori dan Aplikasi. Jakarta: Bumi Aksara. 